\title{
Evaluation of cornea with specular microscopy in patients with ocular rozacea
}

\section{Oküller rozasea hastalarında korneanın speküller mikroskopi ile değerlendirilmesi}

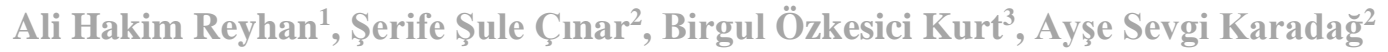

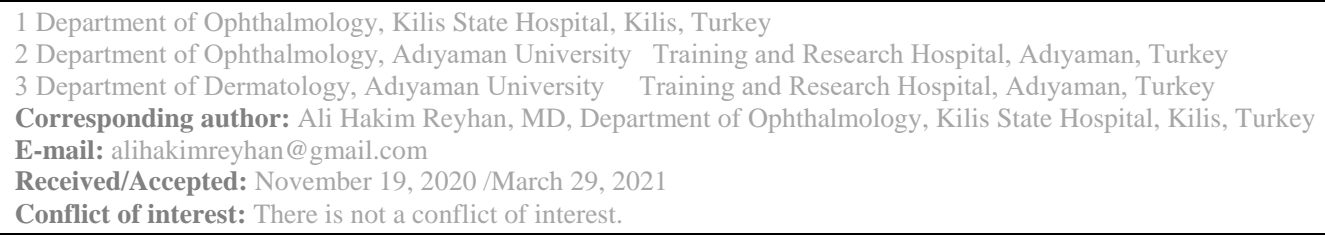

\section{SUMMARY}

Objective: To investigate changes in corneal endothelial cell density, corneal morphology and central corneal thickness in patients with ocular rosacea.

Method: 60 eyes of 30 ocular rosacea patients and 60 eyes of 30 control group with similar demographic characteristics were included in the study. Detailed ophthalmological examination was performed in all individuals participating in the study. The eyes of all participants were evaluated by specular microscopy, schirmer 1 test, tear break-up time test (TBUT). Additionally, via specular microscopy the following parameters were assessed: endothelial cell density (ECD), mean cell area (ACA), minimum cell area (CAmin), maximum cell area (CA max), cell area standard deviation (SD), coefficient of variation in the cell area (CV), hexogonal cell ratio (HEX), central corneal thickness (CCT) numerical (NUM).

Results: Although none of the differences are statistically significant, patients with ocular rosacea have lower ACA, CA min, CA max, HEX, CCT and NUM values $(p=0,169, p=0,897, p=0,694, p=0,649, p=0,164$ and $\mathrm{p}=0,070$, respectively), and higher $\mathrm{CD}, \mathrm{SD}$ and $\mathrm{CV}$ values $(\mathrm{p}=0.509, \mathrm{p}=$ $0.437, \mathrm{p}=0.165$, respectively). In ocular rosacea patients, there was no significant correlation was found the values of mean Schirmer test between CV, HEX, ECD, CT $(\mathrm{p}=0.394, \mathrm{p}=0.906, \mathrm{p}=0.222, \mathrm{p}=0.208$, respectively). Additionally, no significant correlation was found between tear break-up time and CV, HEX, ECD, CCT ( $\mathrm{p}=0.079, \mathrm{p}=0.227, \mathrm{p}=$ $0.621, \mathrm{p}=0.712$, respectively).

Conclusions: Our finding show that, despite the presence of some observable differences, corneal endothelial functions are similar to control group in patients with ocular rosacea.

Keywords: Ocular rosacea, specular microscopy, dry eye syndrome, corneal endothelium.

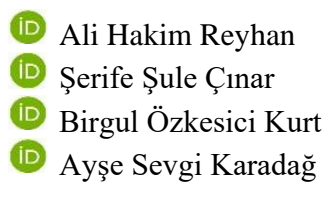

ORCID IDs of the authors: A.H.R. 0000-0001-8402-0954 S..S.C. 0000-0001-8377-0753 B.Ö.K. 0000-0003-3121-5816 A.S.K. 0000-0002-7662-6531 
Yöntem: 30 oküler rozasea hastasının 60 gözü, benzer demografik özelliklere sahip 30 kontrol grubunu bireyin 60 gözü çalışmaya dahil edildi. Çalışmaya katılan tüm bireylerin detaylı oftalmolojik muayene yapıldı. Tüm katılımcıların gözleri speküler mikroskopi, schirmer 1 testi, gözyaşı kırılma zamanı testi ile değerlendirildi. Ayrıca, speküler mikroskopi ile aşağıdaki parametreler değerlendirildi: endotel hücre yoğunluğu (ECD), ortalama hücre alanı (ACA), minimum hücre alanı (CAmin), maksimum hücre alanı (CA max), hücre alanı standart sapması (SD), hücre alanındaki varyasyon katsayısı (CV), heksogonal hücre oranı (HEX), merkezi kornea kalınlığı (CCT), numerik (NUM).

Bulgular: Çalışmamızda oküler rozasea hastaları, sağlıklı kontrollere göre daha düşük ACA, CAmin, CAmax, HEX, CCT, NUM (sırasiylap $=0,169, p=0,897, p=0,694, p=0,649, p=0,164, p=0,070$ ) değerlerine, daha yüksek CD ve $S D, C V$ (sırasıly $p=0,509, p=0,437, p=0,165$ ) değerlerine sahip olmasına rağmen istatistiksel olarak anlamlı fark yoktu. Oküler rozasea hastalarında ortalama Schirmer testi değerleri ile CV, HEX, ECD, CT arasında anlamlı bir korelasyon bulunmadı (sırasıyla $\mathrm{p}=0,394, \mathrm{p}=0,906, \mathrm{p}=0,222, \mathrm{p}=0,208$ ). Ayrıca, gözyaşı kırılma zamanı ile $\mathrm{CV}, \mathrm{HEX}, \mathrm{ECD}, \mathrm{CCT}$ arasında anlamlı bir korelasyon bulunmadi (sirasiyla $\mathrm{p}=0.079, \mathrm{p}=0.227, \mathrm{p}=0.621, \mathrm{p}=0.712$ ).

Sonuç: Bulgularımız göre, oküler rozasea hastalarında korneal endotel fonksiyonların kontrol grubuna göre, bazı farklı1ıkları olmasına rağmen, benzer olduğunu göstermektedir.

Anahtar sözcükler: Oküler rozasea, speküler mikroskopi, kuru göz hastalığı, korneal endotel.

\section{INTRODUCTION}

Rosacea is a chronic inflammatory skin disease of unknown origin, characterized by papules, pustule erythema and telangiectasia in the face and neck ${ }^{1}$. It is estimated that up to $58 \%$ of patients with rosacea also have ocular rosacea ${ }^{2,3,4}$. The degree and characteristics of ocular involvement in rosacea varies greatly, from blepharitis to corneal perforations that may result in vision loss 5,6 . Ocular rosacea usually progresses with nonspecific symptoms such as itching, burning, stinging, redness, foreign body sensation, photophobia, pain and blurred vision. The most common findings are blepharitis, telangiectasia at the edge of the eyelid, meibomitis, recurrent chalazion, hordeolum, superficial punctate keratopathy and conjunctival hyperemia. Less frequently, episcleritis, scleritis, keratitis, iritis corneal vascularization, corneal perforation can be seen ${ }^{7}$. The majority of patients with rosacea also have meibomian gland dysfunction ${ }^{8}$. Meibomian gland dysfunction can cause blepharitis, dry eye syndrome, abnormalities in tear break-up time and schirmer tests, and recurrent chalazions in patients with rosacea ${ }^{9-12}$. The etiopathogenesis of the ocular rosacea remains unknown; however, recently, research has focused on matrix metalloproteinase, bacterial lipases and interleukin lalfa levels in association with blepharitis and corneal epitheliopathy in rosacea patients ${ }^{13}$.

The corneal endothelium is the posterior layer of the cornea that demonstrates a honeycomb pattern consisting of single-row cells. Corneal endothelial cells are the cells responsible for maintaining the transparency of the cornea by regulating stromal hydration ${ }^{14-16}$. Specular microscopy is a noninvasive imaging method to evaluate the morphology of the corneal endothelium. The parameters of endothelial cell density (ECD), coefficient of variation (CV) and percent of hexagonal cells or hexagonal cell ratio (HEX) are usually used to evaluate endothelial morphology and stability. ECD is an important biomarker in evaluating corneal health ${ }^{17}$. The value of ECD is expressed as the number of cells per square millimeter. $\mathrm{CV}$ is an indicator of the homogeneity of the size of endothelial cells; high values indicate high pleomorphism levels ${ }^{18}$. HEX is the ratio of hexagonal cells to cells with other geometric shapes. Although the ideal rate is around $100 \%$, it has been reported that HEX is in the range of 60$70 \%$ in healthy corneas in previous studies ${ }^{19}$. Central corneal thickness (CCT) can be used as a marker that provides information about both the barrier and pump functions of the endothelium and can be measured using specular microscopy ${ }^{20}$.

Chronic inflammation occurring in the corneal endothelium and aqueous humor can cause endothelial cell loss. Although the mechanisms involved in endothelial cell loss are not understood, it has been suggested that the breakdown of the blood-ocular barrier due to chronic subclinical inflammation plays a role ${ }^{21}$. Our hypothesis was that there is a possibility of endothelial damage and endothelial cell dysfunction in a disease such as ocular rosacea that progresses with chronic inflammation. Thus, we aimed to evaluate the corneal endothelial functions and morphology of ocular rosacea in comparison with the eyes of control group.

\section{MATERIAL AND METHODS}

This study was carried out in accordance with the Helsinki declaration. It was carried out after obtaining written informed consent from all participants. Before the study, approval was obtained from the clinical research ethical 
committee of Adiyaman University (Date: 21/11/2017 no: 2017/8-2).

Ocular rosacea group comprised 30 patients with a diagnosis rosacea referred to us from the dermatology department of Adiyaman University. 60 eyes of 30 ocular rosacea patients recruited by the ophthalmology department of Adiyaman University and 60 eyes of 30 control group without ocular and systemic diseases were evaluated.

As per report of the expert committee of the American National Rosacea Society, diagnosis of ocular rosacea was made on the findings of anterior blepharitis, meibomitis and/or meibomian gland dysfunction (MGD), recurrent chalazion, eyelid telangiectasia, punctate epitheliopathy, corneal infiltrates or neovascularization, particularly in the peripheral cornea. The subjects were diagnosed MGD by an experienced ophthalmologist based on ocular symptoms, $\geq 1$ lid margin abnormality (irregular lid margin, vascular engorgement, plugged meibomian gland orifices, and anterior or posterior replacement of the mucocutaneous junction), and poor meibum expression.

Individuals with systemic diseases, Patients with structural abnormalities of the eyelids, aqueousdeficient dry eye, inflammatory or infectious keratitis, a history of any eye disease or eye trauma, those that had undergone eye surgery, and contact lens users were excluded from the study.

The best corrected visual acuity of each patient was evaluated with Snellen chart. Biomicroscopic examination, fundus examination, intraocular pressure measurements with goldmann applanation tonometer were also performed. Both eyes of all ocular rosacea group were evaluated with the schirmer 1 test (without anesthesia) and tear breakup time test (TBUT). Standard Schirmer filter paper (5x35 mm Clement Clarke International) was used for the Schirmer 1 test. Briefly, the first $5 \mathrm{~mm}$ portion was placed in the outer $1 / 3$ conjunctival fornix. After 5 minutes, the amount of wetness was measured. Below $10 \mathrm{~mm}$ was considered significant. TBUT was examined using Haag Streit fluorescein paper without using superficial anesthetic. While the patients were looking upward, the fluorescein paper was smoothly touched to the primary temporal inferior fornix conjunctiva and then removed. The patients were directed to blink three times, and then look straight forward without blinking. The tear film was observed under cobalt blue filtered light of the slitlamp biomicroscope, and the time that elapsed between the last blink and appearance of the first break in the tear film was recorded with a stopwatch. Measurements were repeated three times and the mean TBUT was calculated.

Patients received topical metronidazole prescribed by the dermatology clinic and our standard ophthalmologic treatment regimen. All patients were treated with hot compresses, eyelash base cleansing, preservative-free artificial tear drops (Tears Naturale Free, Alcon, Fort Worth, Texas, USA or Refresh, topical antibiotic ointment (Ciloxan ophthalmic ointment, Alcon), short-term low-dose topical corticosteroid drops (Lotemax, Bausch\&Lomb, Bridgewater, NJ, USA) four times daily, $100 \mathrm{mg}$ oral doxycycline once daily, and topical $0.05 \%$ cyclosporine drops (Restasis, Allergan) four times daily.

The eyes of all participants were evaluated by noncontact specular microscopy (Nidek CEM - 530, Japan). Measurements were made at least 3 times by the same technician using the central method. Endothelial cell density (ECD), average cell area (ACA), minimum cell area (CAmin), maximum cell area (CAmax), standart deviation of cell area (SD), coefficient of variation in cell area $(\mathrm{CV})$, hexagonal cell ratio (HEX), central corneal thickness (CCT) and numeric (NUM) parameters were evaluated.

The evaluation of all data was done with the SPSS version 22.0 (SPSS Inc, Chicago, Illinois, USA) software. Comparison of analyzed parameters between groups was performed with the Chi-square test and independent samples t-test depending on data type (continuous, categorical). In the results, a p-value less than 0.05 was considered to demonstrate statistical significance.

\section{RESULTS}

In the patient group, 3 patients were male and 27 patients were female. The age of individuals in the ocular rosacea group ranged between 23 and 63 years, with a mean of $42.1 \pm 11.3$ years. Similarly, the control group consisted of 3 males and 27 females. Their ages ranged from 26 to 65 years, with a mean of $42.0 \pm 10.6$ years. The groups were homogeneous in terms of age and gender ( $p>0.05$ ). The most common ocular symptoms in ocular rosacea patients were itching $(65.5 \%)$, redness $(61 \%)$, watery eye $(23 \%)$, stinging $(55 \%)$, foreign body sensation (52\%). The most common findings in patients were meibomian gland dysfunction $(68 \%)$, telangiectasia (29\%) blepharitis (55\%), chalazion $(35 \%)$, conjunctival hyperemia $(55 \%)$ and superficial punctate keratopathy (22\%). (Table 1) 
Table 1: Evaluation of symptoms and signs in ocular rosacea patients

\begin{tabular}{|l|c|c|l|c|c|}
\hline Symptom & $\mathbf{n : 6 0}$ & $\mathbf{\%}$ & Findings & $\mathbf{n : 6 0}$ & $\mathbf{\%}$ \\
\hline Itching & 39 & 65,5 & MGD & 41 & 68 \\
\hline Redness & 37 & 61 & Telangiectasia & 14 & 29 \\
\hline Watery Eye & 14 & 23 & Blepharitis & 33 & 55 \\
\hline Stinging & 33 & 55 & Chalazion & 21 & 35 \\
\hline FBS & 31 & 52 & Conjunktival Hyperemia & 33 & 55 \\
\hline & & & SPK & 13 & 22 \\
\hline
\end{tabular}

FBS: Foreign Body Sensation, SPK: Superficial punctate keratopathy, MGD: Meibomian gland dysfunction

The mean schirmer test result was $11.51 \mathrm{~mm}$ in ocular rosacea patients, and the mean tear break-up time result was $7.62 \mathrm{sec}$. The mean intraocular pressure in patients with ocular rosacea was 17.58 $\mathrm{mmHg}$, whereas it was $16.54 \mathrm{mmHg}$ in the control group ( $\mathrm{p}=0.227$ ).. Best corrected visual acuity was 0.91 in the ocular rosacea group and 0.97 in the control group.

No statistically significant difference was found in ECD, CAmin, CAmax, SD, CV, HEX, CCT, NUM values when the rosacea and control groups were compared (Table 2). In ocular rosacea patients, there was no significant correlation was found the values of mean Schirmer test between CV, HEX, ECD, CT ( $\mathrm{p}=0.394, \mathrm{p}=0.906, \mathrm{p}=0.222, \mathrm{p}=$ 0.208 , respectively). Additionally, no significant correlation was found between tear break-up time and CV, HEX, ECD, CCT ( $\mathrm{p}=0.079, \mathrm{p}=0.227, \mathrm{p}$ $=0.621, \mathrm{p}=0.712$, respectively) (Table 3 ).

Table 2: Comparison of specular microscopy and corneal endothelial values in ocular rosacea patients and controls

\begin{tabular}{|l|c|c|c|}
\hline & $\begin{array}{c}\text { Ocular Rosacea } \\
\text { Group }\end{array}$ & $\begin{array}{c}\text { Control } \\
\text { Group }\end{array}$ & P-values \\
\hline CD $\left(\right.$ cells $\left./ \mathrm{mm}^{2}\right)$ & $2577,80 \pm 31$ & $2540,72 \pm 29$ & 0,509 \\
\hline ACA $\mu \mathrm{m}^{2}$ & $384,38 \pm 66,563$ & $399,68 \pm 53,899$ & 0,169 \\
\hline CA min $\mu \mathrm{m}^{2}$ & $141,42 \pm 17,90$ & $141,93 \pm 17,16$ & 0,897 \\
\hline CA max $\mu \mathrm{m}^{2}$ & $1016,77 \pm 305,98$ & $1080,77 \pm 214,36$ & 0,694 \\
\hline SD & $115,22 \pm 27,89$ & $111,80 \pm 19,32$ & 0,437 \\
\hline CV & $30,93 \pm 6,06$ & $29,67 \pm 3,54$ & 0,165 \\
\hline HEX $\%$ & $66,90 \pm 7,25$ & $67,40 \pm 4,40$ & 0,649 \\
\hline CCT $\mu \mathrm{m}$ & $543,52 \pm 31,21$ & $552,13 \pm 35,94$ & 0,164 \\
\hline NUM (cell) & $155,22 \pm 53,28$ & $170,78 \pm 38,34$ & 0,070 \\
\hline
\end{tabular}

CD: Endothelial cell density, ACA: mean cell area, CAmin: minimum cell area, CAmax: maximum cell area, SD: standard deviation of the cell area, CV: variation coefficient in the cell area, HEX: hexogonal cell ratio, CCT: central corneal thickness NUM : numerical 
Table 3: Evaluation of the correlation between dry eye diagnosis tests and specular microscopy parameters in ocular rosacea patients

\begin{tabular}{|l|c|c|}
\hline & Schirmer & TBUT \\
\hline CV & r: $-0,110 p=0,395$ & $r:-0,225 p=0,079$ \\
\hline HEX & r: $-0,15 p=0,906$ & $r: 0,140 p=0,277$ \\
\hline CD & r: $-0,157 p=0,222$ & $r:-0,64 p=0,621$ \\
\hline CCT & r: $-0,162 p=0,208$ & r: $0,048 p=0,712$ \\
\hline
\end{tabular}

TBUT: tear break-up time, CV: coefficient of variation in the cell area, CD: endothelial cell density, HEX: hexagonal cell ratio, CCT: central corneal thickness

\section{DISCUSSION}

Ocular rosacea may cause damage to the cornea due to the presence of chronic inflammation. However, our assessment of corneal endothelial function in patients with ocular rosacea did not show any significant differences from controls, even though some observable differences were determined in patients.

The causes of chronic corneal endothelial cell damage have not been clearly identified ${ }^{22}$. Intraocular operations, glaucoma, chronic inflammation and aging can cause corneal endothelial cell damage ${ }^{23-26}$. Especially endothelial cell disruptions associated with anterior uveitis have been known and studied for a long time ${ }^{27}$. In another study, various disorders and functional losses (that were thought to be due to chronic inflammation) were observed in endothelial cells around keratic precipitates after anterior uveitis ${ }^{28}$. Even though no corneal decompensation was shown in this study, losses in cell morphology were detected. Compared to the fellow eye with no uveitis attack, the eye that developed chronic uveitis-induced keratic precipitate showed significant differences in cell size and cell density, especially around keratic precipitates ${ }^{28}$. However, as stated in the study, these differences disappeared after treatment [28]. It was known that some inflammatory cytokines have endothelial cell loss even in in vitro conditions and may have a toxic effect on endothelial cells ${ }^{29}$. In addition, it has been shown that inflammatory cytokines may be related to endothelial cell loss ${ }^{22}$.

Therefore, it is feasible to suggest that ocular rosacea may lead to significant inflammation that could, in turn, lead to endothelial damage. However, the results of our study demonstrated an absence of meaningful differences between patients and controls. However, we did not assess the uvea and retina, which could have been disproportionately affected by ocular rosacea. For instance, Kheirkhah et al showed corneal endothelial cell loss in patients with dry eye syndrome and their study was guiding for us in this context ${ }^{30}$. Kheirkhah et al showed that patients with dry eye syndrome had a lower level of endothelial cells compared to the normal population, and observed faster cell loss (in excess of age-related loss) in their follow-up ${ }^{30}$. Although the cause of this loss was not explicitly found in this study, the authors emphasized that chronic inflammation could explain their findings ${ }^{30}$. As such, we hypothesized that a disease such as ocular rosacea which often causes dry eye syndrome and is associated with chronic inflammation in the entire body and eyes, could have a comparatively greater effect on endothelial cells. We can explain the lack of meaningful alterations in our study with the treatments received by our patients. Pillai et al stated that the changes they showed in the corneal endothelium due to chronic anterior uveitis decreased with the regression of inflammation; furthermore, they reported that the damage suffered by the epithelium was not permanent after treatment [28]. Therefore, we may associate the absence of significant levels of endothelial cell loss in our study with the administration of antiinflammatory treatments in the patient group. Also, the small sample size of our study may have affected the results. More accurate results may be obtained by increasing the study sample and evaluating the effects of treatments in patients with ocular rosacea.

When we evaluated the relationship between dry eye syndrome and corneal endothelium, we found that there was no correlation between any of the corneal endothelial parameters and results from the Shirmer test and TBUT. There are contradictory studies on this subject in the literature. In some 
studies, it has been reported that patients with dry eye syndrome suffer from damages to the corneal endothelium -with regard to the severity of disease ${ }^{31}$. Additionally, in the same study, they graded dry eye patients according to TBUT and tear menicus heights, which demonstrated a significant worsening in specular microscopy findings that correlated with the severity of dry eye syndrome ${ }^{31}$. In another study, Kreikah et al found ECD reduction in dry eye patients in line with the degree of the disease ${ }^{32}$. It is known that dry eye syndrome initiates an inflammatory process ${ }^{33}$. In these studies, although the mechanism of dry eye syndrome causing endothelial damage cannot be clearly explained, it is said that the inflammatory process in the eye may be effective in this condition 31,32 . There are also publications where these results could not be repeated; for instance, one study reported no significant change in the corneal endothelium in patients with dry eye ${ }^{34}$. Sopapornamorn et al also reported that corneal endothelium density or corneal endothelial morphology were not associated with the parameters of dry eye syndrome ${ }^{34}$. In another interesting study, significant morphological changes were detected in the endothelium only in patients with dystyroid ophthalmopathy; whereas no significant change was determined in other patients with dry eye syndrome ${ }^{35}$. However, the authors could not provide any explanation regarding their findings ${ }^{35}$.

\section{Study Limitations}

The limitations of this study are its retrospective design, the need for a larger patient population and the administration of anti-inflammatory treatments in the patient group

\section{CONCLUSION}

Our results demonstrate that there were no differences between patients with ocular rosacea and control group in terms of corneal endothelial functions. Although all parameters assessed in this study were similar in these two groups, some comparisons were only marginally insignificant; therefore, we believe that future studies that include a higher number of patients that were stratified according to treatments could be instrumental for the accurate assessment of the effects of ocular rosacea on the corneal endothelium.

\section{REFERENCES}

1. Wilkin J, Dahl M, Detmar M. Standard classification of rosacea: report of the national rosacea society expert committee on the classification and staging of rosacea. $\mathrm{J}$ Am Acad Dermatol 2002; 46:584-587.

2. Gessert CE, Bamford JT. Measuring the severity of rosacea. A review. Int $\mathrm{J}$ Dermatol 2003; 42:444-448.

3. Ramelet AA. Rosacea: a reaction pattern associated with ocular lesions and migraine? Arch Dermatol 1994; 130:1448.

4. Quarterman MJ, Johnson DW, Abele DC. Ocular rosacea. Arch Dermatol 1997; 133:495

5. Bakar O, Demircay Z, Toker E, et al. Ocular signs, symptoms and tear function tests of papulopustular rosacea patients receiving azithromycin. J Eur Acad Dermatol Venereol 2009;23: 544-9.

6. Sobolewska B. Ocular rosacea. Haurtartz. 2013; 64:506-508

7. Browning DJ, Proia AD. Ocular Rosacea. Surv Ophthalmol 1986; 31: 145-58

8. Nelson JP, Shimazaki J, Benitez-del-Castillo $\mathrm{JM}$, et al. The international workshop on meibomian gland dysfunction: report of the definition and classification subcommittee. Invest Ophthalmol Vis Sci 2011; 52:1930-7.

9. Awais M, Anwar MI, Iftikhar R, et al. Rosacea - the ophthalmicperspective. Cutan Ocul Toxicol 2015; 34:161-6.

10. McCulley JP, Dougherty JM. Bacterial aspects of chronic blepharitis. Trans Ophthalmol Soc UK 1986; 105:314-8.

11. Lemp MA, Mahmood MA, Weiler HH. Association of rosacea and keratoconjunctivitis sicca. Arch Ophthalmol 1984; 102:5567.

12. Lempert SL, Jenkins MS, Brown SI. Chalazia and rosacea. Ophthalmology 1979; 97:1652-3.

13. Stone DU, Chodosh J. Ocular rosacea: an update on pathogenesis and therapy. Curr Openion Ophthalmol 2004; 15:499-502.

14. Van den Bogerd B, Zakaria N, Adam B, et al. Corneal Endothelial Cells Over the Past Decade: Are We Missing the Mark (er)? Translational vision science \& technology 2019;8: 13-13.

15. Greene DA, Yagihashi S, Lattimer SA, et al. Nerve Na+-K+-ATPase, conduction, and myoinositol in the insulin-deficient BB rat. Am J Physiol 1984; 247:534-539.

16. Watsky MA, McDermott ML, Edelhauser HF. In vitro corneal endothelial permeability in 
rabbit and human: the effects of age, cataract surgery and diabetes. Exp Eye Res 1989; 49:751-767.

17. Shi Y, Huang J, Baghdasaryan E, et al. Representation of central endothelial cell density by analysis of single best specular microscopy image regardless of cell size variance. Translational Vision Science \& Technology 2019;8: 23-23.

18. Sahu PK, Das GK, Agrawal $\mathrm{S}$, et al. Comparative evaluation of corneal endothelium in patients with diabetes undergoing phacoemulsification. Middle East African journal of ophthalmology 2017;24: 74.

19. González-Méijome JM, Jorge J, Queirós A, et al. Two single descriptors of endothelial polymegethism and pleomorphism. Graefes Arch Clin Exp Ophthalmol 2010; 248:11591166.

20. Ponce CMP, Rocha, KM, Smith SD, et al. Central and peripheral corneal thickness measured with optical coherence tomography, Scheimpflug imaging, and ultrasound pachymetry in normal, keratoconus-suspect, and post-laser in situ keratomileusis eyes. Journal of Cataract \& Refractive Surgery 2009; 35: 1055-1062.

21. Armitage WJ, Dick AD, Bourne WM. Predicting endothelial cell loss and long-term corneal graft survival. Invest Ophthalmol Vis Sci 2003; 44:3326-3331.

22. Yagi-Yaguchi Y, Yamaguchi T, Higa K, et al. Association between corneal endothelial cell densities and elevated cytokine levels in the aqueous humor. Sci Rep 2017;7: 1-8.

23. Wilson RS, Roper-Hall MJ. Effect of age on the endothelial cell count in the normal eye. $\mathrm{Br} \mathrm{J}$ Ophthalmol 1982; 66:513-515.

24. Bigar

$\mathrm{F}$, Witmer

$\mathrm{R}$.

Corneal endothelial changes in primary acute angle-closure glaucoma. Ophthalmology 1982; 89:596-9.
25. Janson BJ, Alward WL, Kwon YH, et al. ScienceDirect Glaucoma-associated corneal endothelial cell damage: A review. Survey of Ophthalmology 2018; 63:500-506

26. Hwang DG, Smith RE. Corneal Complications of Cataract surgery. J Refract Surg 1991; 7: 7780.

27. Alfawaz AM, Holland GN, Yu F, et al. Corneal Endothelium in Patients with Anterior Uveitis. Ophthalmology 2016; 123:1637-1645.

28. Pillai CT, Dua HS, Azuara-Blanco A, et al. Evaluation of corneal endothelium and keratic precipitates by specular microscopy in anterior uveitis British Journal of Ophthalmology 2000; 84:1367-1371.

29. Sagoo P, Chan G, Larkin DF, et al. Inflammatory cytokines induce apoptosis of co rneal endothelium through nitric oxide. Invest Ophthalmol Vis Sci 2004;45: 3964-73.

30. Kheirkhah A, Satitpitakul V, Hamrah P, et al. Patients with Dry Eye Disease and Low Subbasal Nerve Density Are at High Risk for Accelerated Corneal Endothelial Cell Loss. Cornea 2017; 36:196-201.

31. Fahmy R. Correlation between Corneal Endothelial Cell Characteristics and Dry Eye Disease. Med Surg Ophthal Res 2018; 1: 1-7.

32. Kheirkhah A, Saboo, US, Abud TB, et al. Reduced Corneal Endothelial Cell Density in Patients With Dry Eye Disease. American Journal of Ophthalmology 2015; 159: 10221026.

33. Stevenson W, Chauhan SK, Dana R. Dry Eye Disease: An Immune-Mediated Ocular Surface Disorder. Arch Ophthalmol 2012;130: 90-100.

34. Sopapornamorn N, Lekskul M, Panichkul S. Corneal endothelial cell density and morphology in Phramongkutklao Hospital. Clin Ophthalmol 2008;2:147-51.

35. Erdélyi B, Kraak R, Zhivov A, et al. In vivo confocal laser scanning microscopy of the cornea in dry eye. Graefe's Arch Clin Exp Ophthalmol 2007;245: 39-44. 